This item was submitted to Loughborough's Research Repository by the author.

Items in Figshare are protected by copyright, with all rights reserved, unless otherwise indicated.

\title{
Services offshoring: a microfoundations perspective
}

PLEASE CITE THE PUBLISHED VERSION

https://doi.org/10.1007/978-3-319-70305-3_1

\section{PUBLISHER}

(C) Springer

\section{VERSION}

AM (Accepted Manuscript)

\section{PUBLISHER STATEMENT}

This work is made available according to the conditions of the Creative Commons Attribution-NonCommercialNoDerivatives 4.0 International (CC BY-NC-ND 4.0) licence. Full details of this licence are available at: https://creativecommons.org/licenses/by-nc-nd/4.0/

\section{LICENCE}

CC BY-NC-ND 4.0

\section{REPOSITORY RECORD}

Gerogiannis, llias, Angelika Zimmermann, and Alexander D. Wilson. 2019. "Services Offshoring: A Microfoundations Perspective". figshare. https://hdl.handle.net/2134/27916. 


\title{
Services offshoring: a microfoundations perspective
}

\author{
Ilias Gerogiannis ${ }^{(\varpi)}$, Angelika Zimmermann, and Alex Wilson \\ School of Business and Economics, Loughborough University, Loughborough, UK \\ \{I.Gerogiannis, A.Zimmermann, A.Wilson8\}@lboro.ac.uk
}

\begin{abstract}
The objective of this paper is to shed light on the link between services offshoring strategy and its outcomes for the firm by developing a theoretical framework for examining the role of employee motivation in the implementation of services offshoring strategy. Our framework is built on two conceptual foundations: the Microfoundations view of strategy and Goal Framing theory. We analyze services offshoring in terms of (a) the attributes and (b) the outcomes of firm level offshoring strategies, and (c) the micro-level processes that are essential for realizing the outcomes. As part of these microlevel processes, we focus particularly on employee motivation for services offshoring strategy implementation. We argue that our framework should constitute the basis of future empirical research in services offshoring, as it aims to contribute a greater theoretical understanding and practical recommendations for the refinement of services offshoring strategies.
\end{abstract}

Keywords: Services offshoring · Microfoundations · Employee motivation · Goal framing theory

\section{Introduction}

For over a decade, the services offshoring phenomenon has attracted the attention of practitioners [1], scholars [2] and policy makers [3]. Services offshoring refers to the transnational transfer of service activities to foreign destinations in captive, collaborative or outsourced governance modes [4-7]. Compared to offshoring of production activities, services offshoring depends more on individual organizational members' knowledge, skills and competences (i.e. human capital) as sources of firm competitive advantage [8, 9].

Aiming for a better understanding of what drives the success of services offshoring initiatives, scholars have progressively investigated (a) services offshoring attributes (e.g. [5, 10, 11]), (b) services offshoring outcomes (e.g. [12-14]) and (c) micro-level processes (e.g. onshore and offshore employee motivational processes) that underlie the services offshoring strategy implementation $[15,16]$. However, the focus of most extant research into services offshoring is pitched at the firm level of analysis rather than at individual actors and teams (i.e. the micro level of analysis), and we know little about the links between the micro and macro levels [6]. We therefore argue that a comprehensive synthesis is needed to understand the link between the macro and micro levels of analysis and to support our understanding of how micro-level processes aggregate into services offshoring strategy outcomes. We pay special 
attention to how a strategy is implemented at the micro level and thereby affects services offshoring strategy outcomes.

This paper situates the above argument within the Microfoundations (MFs) view of strategy. The MFs movement in strategy and organization theory provides the means to understand how micro-processes mediate relations between macro-variables (such as firm or business level strategy and firm / business level outcomes) [17]. In the same line, we hold that the macro-level phenomena of (a) services offshoring strategy and (b) its realized outcomes are linked to micro-level processes in terms of actions and interactions of individual organizational members (i.e. managers and employees) that work towards putting the strategy into effect (i.e. strategy implementation).

In this paper we pay particular attention to the role of employee motivation in the implementation of services offshoring strategy, in order to understand how the realized outcomes are generated. Services firms are seen to encounter several offshoring implementation challenges [18], some of which are tied to motivational processes amongst onshore and offshore employees [16]. Despite its apparent importance, the role of employee motivation in services offshoring strategy implementation has received little consideration among scholars until now [16]. We examine employee motivation through two theoretical lenses, the Microfoundations (MFs) perspective on strategy and Goal Framing theory (GFT).

The MFs literature suggests that micro-processes in the context of individual motivations and their behavior (i.e. actions and interactions) could be explored with the use of goal framing theory (GFT) [19, 20]. GFT suggests that in principle there are three overarching goals that individuals pursue: the hedonic and gain goals regarding personal needs and self-interest, and the normative goal concerning the need to work towards the realization of collective interests. GFT provides the lens through which to explore the microfoundations of strategy by using the concept of "joint production motivation". A joint production motivation is a motivation of individuals to contribute to a joint effort with their own "roles and responsibilities" and also with a shared understanding of "the relevant tasks, interdependencies, timing and possible obstacles to smooth coordination" [19, p. 89]. In other words, an employee / manager who pursues normative goals holds a joint production motivation. Based on these insights, we apply GFT to address employee motivations in services offshoring strategy implementation, and further suggest that joint production motivation can play a key role in the implementation of services offshoring strategy.

The rest of the paper is structured as follows: First we present a background description of the Microfoundations view of strategy and the use of GFT for MFs research. We then discuss firm-level attributes of services offshoring strategies and firm level outcomes of services offshoring in order to explore extant offshoring research from a macro / firm level perspective. Considering various levels of the services offshoring phenomenon, we next focus on previous insights into microprocesses of services offshoring strategy, and highlight blind spots and gaps in existing research on such micro-processes. We then propose a conceptual model for research on the microfoundations of services offshoring strategy. Following this, we elaborate on how GFT can be used to address the role of employee motivation in services offshoring strategy implementation. This leads to three propositions, concerning (1) how offshoring strategies can trigger joint production motivation and 
how this is a prerequisite for successful strategy implementation, (2) how the microprocesses of interpersonal relationships and relational signals impact on the microprocesses of employee motivation in services offshoring and (3) how joint production motivation may affect knowledge sharing (an essential condition for effective services offshoring outcomes). Finally, we highlight the managerial relevance of the proposed theoretical framework and identify possible directions for future research.

\section{The Microfoundations View of Strategy and Goal Framing Theory}

We build on the growing body of research that suggests a missing link between macro and micro aspects in strategy research [17]. Foss and Lindenberg [19] argue that this gap should be addressed through a focus on the cognitions and motivations of organizational members, using a 'micro-foundations of strategy' approach. The methodological perspective of MFs advocates that the micro level constitutes the basis, or the starting point, for the exploration of a collective phenomenon such as the central strategy aims of value creation and competitive advantage [17]. This approach points to individual(s)' actions and interactions as the ultimate possible element of analysis [17]. In this context, the explanatory role of macro-level variable(s) (including firm or business unit level strategy) is still considered present and significant. However, no direct macro-causation is deemed eligible for the explanation of collective phenomena without the presence of a micro-level mediation [17].

We adopt this MFs view of strategy in order to explore the role of employee motivation in the implementation of services offshoring. We assume that a services offshoring strategy is an aggregate phenomenon that takes place as a process across the macro / firm level and the micro / employee-team level. We therefore suggest that a MFs view of services offshoring strategy enables the inspection of employees' motivations to support offshoring and that certain actions and interactions of individuals drive the implementation of the offshoring strategy, which in turn affects firm-level outcomes.

According to GFT in turn, 'framing' is a cognitive process that governs human behavior, and frames are triggered by cues from the environment [19]. In the same line, we propose that an offshoring strategy provides cues that trigger the framing process in individuals. In detail, there are three overarching goals: the hedonic, the gain and the normative goals [19, p. 87]. The hedonic goal is linked to the desire for satisfaction (how one feels right now), the gain goal relates to the need to acquire and / or preserve one's own resources (or efficiency of resources) and the normative goal refers to the need to act appropriately and work collectively in relation to group goals and a joint production framework [19]. Such goals are "overarching", because they entail other relevant sub-goals [19, p. 88].

GFT posits that when a situational cue triggers one of the main overarching goals, a frame (i.e. a specific state of mind) is created whereby one of the overarching goals is focal. However, overarching goals are interrelated: when one of the above three overarching goals is triggered and thereby becomes the focal goal, the remaining two background goals can still be influential. Thus, a frame can be stronger or weaker 
depending on the influence of its background goals [19]. Motivations can be mixed and heterogeneous since foreground and background goals are simultaneously operative [19].

\section{Firm Level Services Offshoring Attributes and Outcomes}

In the following section we summarize and discuss extant research on services offshoring as a macro-level construct. We review how extant research conceptualizes and empirically investigates: (a) firm level attributes of services offshoring, and (b) firm level services offshoring outcomes, and we point out how these two are interlinked. Following the MFs perspective, we then advocate that extant views on firm level services offshoring attributes and their outcomes provide only incomplete explanations. In particular, we hold that they need to be complemented by a focus on micro-processes that entail services offshoring strategy implementation.

\subsection{Strategic Attributes of Services Offshoring}

Several theories derived from various academic streams such as Strategic Management and International Business are relevant to the offshoring phenomenon as presented in the services offshoring and outsourcing literature (e.g. [4, 21-23]). The outsourcing literature is here relevant because it includes offshore outsourcing as a particular type of outsourcing. These theories can serve to describe certain strategic attributes of services offshoring in terms of motives or intended outcomes of services offshoring. Based on the concepts of competitive advantage and value chain [24], a services offshoring strategy is seen as a competitive strategy that aims at and potentially contributes to value creation and competitive advantage. To provide an example, Maskell et al.'s [25] empirical data from Danish firms in various industries and functions, including production of goods as well as services, suggest that the main three drivers for offshore outsourcing are cost reduction motives that can contribute to cost leadership, or quality-seeking motives and innovation motives that can create differentiation advantages.

According to the resource based view of the firm (RBV) in turn, offshoring and outsourcing decisions can be explained by a focus on strategic capabilities and resources that enable a sustained competitive advantage [26]. For example, the RBV provides a useful framework for the analysis of the role of internal firm capabilities (i.e. international and technical experience to deal with the offshoring process and leverage knowledge) for knowledge-seeking firms that offshore R\&D activities [27, p. 18]. In the same vein, Manning et al. [7] hold that strategic firm capabilities including strategic talent management and collaborating effectively with external partners offshore can be considered as dynamic capabilities (see [28]) that allow the firms to face challenges (e.g. high turnover rates) and adapt to a dynamic offshoring environment (e.g. collaboration with new partners). The knowledge based view of the firm (KBV) emphasizes that offshoring is a firm strategy that aims at expanding the firm's knowledge resources. For example, in the case of advanced task offshoring, firms seek to leverage the knowledge assets of a skilled workforce (e.g. [10, 29]). 
Furthermore, transaction cost economics (TCE) can provide a basic explanation of offshoring decisions, based on cost efficiency and control choices over parts of the firm's value chain [30]. The OLI paradigm [31,32] in turn provides a framework to explain offshoring / outsourcing strategic decisions in terms of a firm's motives (e.g. market seeking) [29].

Overall, scholars have identified various strategic attributes of service work offshoring, including cost efficiency, access to a skilled workforce, and access to new markets (see e.g. [5, 10, 11]). Whilst the prime and most commonly mentioned strategic attribute refers to cost motivations based on reduced labor costs (see [33]), scholars suggest that in the case of advanced services offshoring, the more central strategic firm goal is to foster international competitiveness through the expansion of knowledge resources and access to global talent pools [10, 11, 34].

\subsection{Operational Attributes of Services Offshoring}

Apart from their strategic attributes, offshoring strategies also have operational attributes including governance modes as well as functions, activities or tasks to be offshored [35]. As we propose later, these operational attributes impact on employeelevel motivational processes in the implementation of services offshoring.

For example, offshoring strategies encompass mechanisms of formal and relational governance of offshoring relationships that aim to align and coordinate the goals, strategies, values and activities of the collaborating stakeholders [36]. Formal governance refers to the use of service level agreements (legal contractual agreements), key performance indicators and other formal control tools, whereas relational governance uses "softer" social control practices focusing on human relations [37]. Scholars have demonstrated the importance of various aspects of relational governance for successful outsourcing, including trust, commitment, open communication and mutual dependency between the outsourcing partners (see [37, pp. 506-508]). Researchers have also suggested that relational governance can substitute or complement formal governance (e.g. [37]). However, research on relational governance is generally limited to the actions and interactions of managers, and the possible role of lower-level employees in offshoring implementation is only implicit.

Furthermore, task interdependencies in distributed work may have a negative impact on firm performance [38]. In distributed work, coordination mechanisms such as task modularity, ongoing communication and tacit coordination mechanisms (i.e. pre-project familiarity, shared knowledge of work procedures and visibility of information across locations) are therefore likely to be required to ameliorate firm performance [38].

\subsection{Services Offshoring Attributes and Firm Level Outcomes: the Missing View on Micro-Processes}

Overall, existing research on strategic firm-level services offshoring attributes suggests that services offshoring includes many motives apart from cost reduction, 
especially where the need for a skilled workforce becomes paramount as in the case of advanced services offshoring. Accordingly, services offshoring outcomes can be classified into two subgroups by the outcomes sought: (a) organizational performance outcomes and (b) capabilities, resources and processes, as an aftermath of offshoring strategy implementation [6,39]. These outcomes are relevant to the various strategic attributes of service offshoring discussed above, namely the motive to achieve cost efficiency, access to skilled work, or access to new markets, which can also be called intended outcomes. Overall, the named outcomes constitute the preconditions for firm competitive advantage and value creation. Various operational offshoring characteristics, including governance mechanisms and choice of activities to be offshored, are used to achieve intended offshoring outcomes.

Offshoring and outsourcing research does however not provide a clear view on how services offshoring strategies result in specific services offshoring outcomes. In other words, limited evidence is provided on the link between services offshoring strategy (i.e. strategic and operational attributes) and organizational outcomes such as performance, capabilities and resources. We hold that in particular, research is needed on the micro-level processes that underlie the link between services offshoring strategies and their outcomes.

A number of researchers have indeed demonstrated an association between services offshoring and certain firm level outcomes, but they have not considered the micro-level processes that underlie this association. Di Gregorio et al. [40] highlight that offshore outsourcing of administrative and technical services in SMEs has a positive effect on their international competitiveness (i.e. export performance), and Larsen et al. [12] report on cost estimation errors in services offshoring decisions. Furthermore, Jensen $[13,14]$ contends that offshoring capabilities evolve over time as the firms gain experience in services offshoring, and Manning [18] highlights in a more nuanced way how firm capability develops as a response to services offshoring implementation challenges, where offshoring firms decide to mitigate, tolerate or relocate depending predominately on their available resources.

These scholars examine services offshoring and its outcomes as independent and dependent variables at the firm or business (macro) level. They also examine the relationships between these macro variables, but without addressing the possible role of micro-level variables in this relationship. Only a few studies have explored microlevel processes within services offshoring. This set of studies has in turn not given a lot of consideration to macro level outcomes. In the following section, we will review this research with the aim to explore the role of micro-level processes in services offshoring strategy implementation.

\section{Micro-Level Processes Linked with Services Offshoring}

In the following section we summarize and discuss extant research on micro-level processes in services offshoring and outline its limitations. As we describe below, the term "micro-level processes" is an encompassing term pointing to individual (i.e. organizational members), team and small group level processes. We identify two different research foci in this micro-literature that involve various levels of analysis: 
(a) a focus on the impact of a macro (i.e. firm level) / meso (i.e. business unit level) services offshoring strategy on micro-level processes and (b) a focus on the role of micro-level processes in services offshoring strategy implementation that results in micro (i.e. team / small group) outcomes, meso (i.e. business unit) outcomes and macro (i.e. firm level) outcomes.

\subsection{The Impact of a Services Offshoring Strategy on Micro-Level Processes}

Regarding the first focus (i.e. how the services offshoring strategy impacts on microlevel processes), extant research explores how offshoring arrangements exert influence on the organizational members, responsible for the operational execution of the strategy. For example, Mattarelli and Tagliaventi [15] hold that a divergence between professional identity and offshore allocated tasks triggers job dissatisfaction among offshore employees, which can result in turnover or job crafting behaviours, depending on the organizational recognition of novelty and social support [15]. Similarly, Zimmermann and Ravishankar [41] discuss how an IT offshoring strategy reconfigures the employee professional role identities and career expectations, as a result of the allocated tasks and the required intercultural communication skills. Likewise, Zimmermann and Ravishankar [16] describe elements of an advanced tasks offshoring strategy that impact on onshore and offshore employee motivation. Such elements are "(a) the complexity and non-routineness of tasks, (b) the level of managerial responsibility allocated offshore and (c) the clarity of plans for distribution of tasks and the managerial responsibility onshore-offshore" [16, p. 554].

Furthermore, scholars focus on effective ways to coordinate globally distributed teams and discuss how a services offshoring strategy facilitates (or not) the cooperation between these teams. For example, Sidhu and Volberda [42], propose that an offshoring strategy that promotes (a) joint rewards between onshore and offshore teams, (b) project involvement of the offshore team at an early stage and (c) horizontal communication, has a positive impact on how geographically dispersed teams cooperate in captive offshoring. Conversely, they suggest that an offshoring strategy that enforces a homogeneous organizational identity and work context (similar to the one at the onshore organisation), may trigger negative emotions and confusion to offshore employees and result in deficient onshore - offshore task coordination.

\subsection{The Role of the Micro-Level Processes in Services Offshoring Strategy Implementation}

In relation to the second focus of the micro-literature, scholars maintain that the implementation of a services offshoring strategy is linked with the way individuals think, behave and feel (e.g. [15, 41]). In detail, extant research on micro-level processes of services offshoring strategies pertinent to strategy implementation touches primarily upon aspects of (a) the onshore and offshore employee collaboration, (b) the role of knowledge transfer in strategy implementation and c) the 
links between micro-level processes, strategy implementation and the evolution of offshoring strategies.

The fruitful collaboration between geographically dispersed teams is commonly considered as a requirement for successful services offshoring (e.g. [43]). Hence, uncertainties about social order [44] and intergroup processes of informal status closure [45] are seen as reasons for problematic collaborations in geographically distributed teams working in services offshoring settings. Asymmetric power relations and status differentials in services offshoring project teams may even result in the "paradox of success", where onshore teams believe that they have more to lose than to benefit from the successful implementation of a project [44, p. 373, 45, p. 11]. In this situation, onshore employees can be reluctant to offshore advanced tasks (e.g. highend IT tasks; [44]). Evidence also suggests that onshore employees perceive the services offshoring strategy differently depending on the complexity of their tasks [46]. In the case of simple routine tasks, services offshoring can be seen as a chance for professional and personal development (e.g. an opportunity for professional and intercultural learning), whereas in the case of more complex and advanced tasks, services offshoring may be perceived as a threat for their jobs and future career [46], as described above regarding the "paradox of success". Conversely, offshore employees can lack motivation to support the services offshoring strategy if they perceive offshored tasks to be insufficiently demanding [16].

Employees' active involvement in knowledge transfer is also important for the implementation of a services offshoring strategy, especially in the case of advanced tasks [46-49]. Zimmermann and Ravishankar [49] propose that knowledge senders' outcome expectations and efficacy beliefs, jointly with social capital, play a key motivational role in knowledge transfer processes. These psychological mechanisms are seen to constitute interlinked self-reinforcing motivational circles of "knowledge transfer success" that affect onshore employees' ability and willingness to transfer knowledge [49]. Interestingly, there are indications that the willingness of onshore employees to transfer their knowledge is less hindered by their job insecurity if they have strong personal relationships with the offshore employees [49].

Scholars also discuss how the services offshoring strategy changes and develops as a result of the successful (or not successful) implementation of the initial strategy [15, 16]. In detail, Mattarelli and Tagliaventi [15] discuss the impact of micro-processes (i.e. job crafting ) on the evolution of firm services offshoring strategy based on employee new ideas. In a recent study, Zimmermann and Ravishankar [16] propose that the "offshoring system" comprises three interlinked organizational elements: the firm-level strategy and the employee motivations onshore and offshore. Bilateral interdependencies exist between the onshore and offshore motivational drivers, as well as between the services offshoring strategy and the motivational drivers in each site. As the authors contend, the motivational drivers for advanced task transfer onshore are formed by the employees' outcome expectations for their careers, their workload and the offshore task performance. For the offshore site, motivations include the levels of task ownership and career expectations. Firm-level strategy and micro-level motivational drivers for its implementation are therefore seen to be interdependent. 


\subsection{Research Gaps and Blind Spots Regarding Micro-Processes of Services Offshoring}

Overall there is some theoretical and empirical support to show that services offshoring success rests on micro-level factors that underwrite or jeopardise its implementation. However, research on this topic is still scarce, and theory building is in its beginnings (e.g. see [16, 49]). Furthermore, we contend that the analysis of strategy implementation in extant research is limited because of lacking operationalizations of the concepts of services offshoring strategy, its implementation and its outcomes, in terms of levels of analysis. Although extant research aims at exploring firm / business unit level offshoring strategies, its focus primarily is on the execution of the operational aspects of an offshoring strategy (e.g. transfer and execution of specific tasks), rather than incorporating outright explanations on the link between operational strategy outcomes and strategic firm / business unit level outcomes.

Therefore, while scholars discuss the effect of micro-processes on services offshoring implementation, there are limited explanations on consequences for macrolevel offshoring outcomes in financial terms (i.e. organizational performance) or in non-financial terms (e.g. firm capabilities and resources). Jensen and Nardi [45] do consider such consequences, discussing how the problematic intergroup cooperation in an offshoring software development project resulted in partial reshoring and unexpected costs, but without analysing this effect in detail. Moreover, scholars discuss the impact of micro-processes on the evolution of operational aspects of firm offshoring strategy (e.g. transfer of new tasks or transfer of more advanced tasks) based on employee job crafting [15] or employee motivational processes [16], but without describing how employee-level motivational processes influence organizational performance outcomes or firm capabilities and resources. To conclude, we believe that more empirical and theoretical underpinning is needed to draw conclusions on how micro-level motivational mechanisms affect certain macro-level outcomes in services offshoring.

\section{Conceptual Model for Services Offshoring Strategy Research}

As mentioned before, based on the MFs perspective, we consider that the link between services offshoring strategy and its microfoundations still needs further exploration. In the following section we will use GFT to suggest how employee motivations are likely to be interlinked with a services offshoring strategy, its implementation and firm level outcomes, leading to specific propositions regarding these interlinkages. The propositions are incorporated in our theoretical model, shown in Fig. 1. 
Macro level

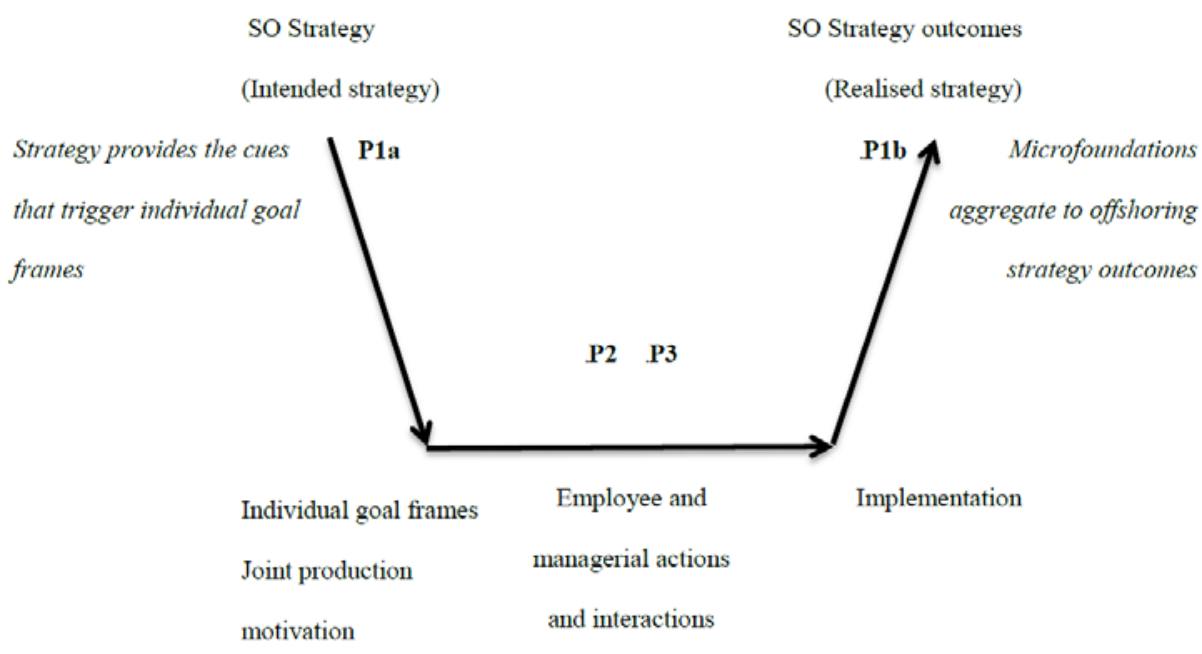

(Microfoundations)

Meso/ Micro level

Fig. 1. Conceptual model for services offshoring (SO) strategy research

The core mechanism in GFT is that cues from the social environment can directly trigger the goal frames that an individual holds, or indirectly increase or decrease the relative strength of existing goal frames. We argue that a services offshoring strategy will provide cues that trigger the goal framing of individuals involved in the offshoring setting (see left hand arrow in Fig. 1). Importantly, to the degree that the strategy provides cues that trigger normative goal frames, employees' joint production motivation will be strengthened (see bottom left in Fig. 1). GFT can therefore help us investigate how employees are motivated to implement a services offshoring strategy, what the goals are that they want to pursue, what the prevailing goal frames are and what stabilizes these goal frames. Based on the MFs view of strategy, we further suggest that the individual goal frames direct employee and managerial actions and interactions and impact on strategy implementation (see bottom arrow in Fig. 1), which in turn affects the macro level outcomes of the services offshoring strategy (see right hand arrow in Fig. 1). On the whole, individual goal frames and actions / interactions together with strategy implementation constitute the microfoundations that aggregate into specific services offshoring outcomes (i.e. (a) organizational performance outcomes and / or (b) capabilities and resources. To conclude, the conceptual model describes the effect of a services offshoring strategy on its outcomes as a multi-level phenomenon. Its core key element is the employee motivation to implement the intended services offshoring strategy. 


\section{Goal Framing Theory and the Microfoundations of Services Offshoring Strategies}

\subsection{Services Offshoring Strategies That Trigger Joint Production Motivation}

Foss and Lindenberg [19] suggest that GFT allows us to explore the cross-level connections between macro and micro levels of analysis, which is in line with the MFs perspective. In order to examine macro-level phenomena (here a services offshoring strategy and its outcomes), we need to focus on the actions and interactions of individuals (i.e. managers and employees). Therefore, we argue that the services offshoring strategy provides the cues that "frame" the goals of employees. Possible cues are (a) the strategy as articulated by a manager in terms of planning (processes and people involved in terms of organizational design and tasks) and (b) what this strategy aims at (e.g. cost savings) or entails, particularly for employees (e.g. the possibility for employees to engage in more interesting tasks). Such cues can trigger certain goal frames that support or do not support the services offshoring strategy implementation.

In detail, building upon extant literature on joint production motivation [19, 20] we propose that a services offshoring strategy based on transparent team and task structures, clear collective goals, and cognitive / symbolic management (i.e. vision / mission statements and relational signaling), directly supports the normative goal frames and initiates joint production motivation. To illustrate, transparent team and task structures, clear collective goals, and cognitive / symbolic management for both onshore and offshore employees will trigger normative goal frames and thereby incite employees to support the services offshoring strategy implementation and focus on acting appropriately towards the common benefit. This is likely to decrease the extent to which they will promote only their own individual financial and social status (e.g. financial rewards, career prospects) that would be in line with gain goals, or enjoyment (e.g. enjoyable tasks) which would be in line with a hedonic goal frame. In addition, rewards that are geared to joint goals are likely to stabilize the normative goals of employees and maintain the joint production motivation [20]. For example, Lindenberg and Foss [20] suggest that gain contingent rewards (e.g. career promotion) and hedonic contingent rewards (e.g. bigger offices) are necessary to keep normative goal frames from decaying. Likewise, we postulate that this could also be the case in a services offshoring setting. Furthermore, based on Foss and Milagres [50], we consider that joint production motivation of onshore as well as offshore employees can take place not only in the case of captive offshoring (i.e. intra-firm collaboration), but also in the case of offshore outsourcing (i.e. beyond the firm boundaries), if a shared offshoring purpose is established for onshore as well as offshore employees. This speculation is in line with a core assumption of Goal Framing theory: cues that convey the information that a social situation refers to a joint project will trigger a normative goal frame, conversely to cues that convey the information that a social situation is a "competitive" or an "economic" one and will thus trigger a gain goal frame [51, p. 672]. We therefore put forward the following proposition: 


\section{Proposition 1a (P1a)}

A services offshoring strategy that provides cues for joint effort of offshore and onshore employees is more likely to contribute to a normative goal frame and thereby joint production motivation, compared to a services offshoring strategy that provides cues that trigger or stabilize gain or hedonic goal frames.

The reasons why a firm makes specific offshoring decisions (from cost efficiency to knowledge seeking motives), what these decisions entail (e.g. possible job reduction measures, organizational restructuring or transfer of specific tasks) and how these decisions translate into a services offshoring strategy, provide cues to the onshore employees that signal a prevailing firm gain. Thus, a prevailing firm gain can explain why onshore employees may express fears (e.g. possible loss of jobs) and are not willing to contribute to the implementation of the services offshoring strategy. Perceptions of job insecurity onshore may exist at all stages of services offshoring (e.g. [41, 45, 52]). As discussed above, the "paradox of success" has a negative impact on onshore employee motivation to transfer knowledge [41, 44] and collaboration [45]. When the services offshoring strategy as planned and executed does not signal managerial interest in employee concerns about losing their jobs, onshore employees try to feel better while dealing with frustration and uncertainty as the outcome of their prevailing hedonic goal frames, or focus primarily on their individual concerns on preserving their jobs / resources / tasks, while in a gain goal frame. For example, Zimmermann and Ravishankar [41] describe onshore employees who intentionally transferred tasks offshore without providing adequate support, in order to get the tasks back (i.e. gain goal frame) and unfairly blamed offshore employees for mistakes (i.e. hedonic goal frame).

Similarly, offshore firms (captives or external providers) may be dealing with high employee turnover rates (e.g. see [53, 54]) and job dissatisfaction (e.g. [15]). We suggest that turnover behaviors and job dissatisfaction may be the outcome of the prevailing firm gain and its impact on employees' individual goals, especially in the context of services offshoring strategy implementation. For example, if an offshore firm and its management are concerned with the implementation of a services offshoring strategy mainly in terms of good financial results and future contractual agreements, the cues towards offshore employees may suggest that their firm is in a gain goal frame. Thus, if the main concern of the offshore firms is to provide services with the minimum financial cost, cues will hinder employee normative goal frames and may foster their gain goal frames (e.g. leaving this company for another one that provides a better salary, status or career prospects) or even their hedonic goal frames (leading in some cases to sabotage or revenge behaviors). Likewise, we reason that when a services offshoring strategy does not involve the transfer of interesting tasks to the offshore employees (e.g. [41]), this may provide cues that will not support the offshore employees' normative goal frames, but would mostly trigger their gain goal frames, for example their focus on career progress, and hedonic goal frames, for example their need to feel better by lowering their expectations from their work.

Furthermore, based on GFT, scholars contend that the normative goal frame is linked with the highest levels of firm value creation (i.e. organizational performance 
characterized by productivity gains and innovativeness), since it can motivate organizational members to work in concert, in truly collaborative activities (i.e. joint production motivation) [19, p. 89]. Building on these insights, we argue that value creation is linked also to the successful implementation of services offshoring.

Moreover, Foss and Lindenberg [19, p. 89] contend that when a firm makes strategic decisions on what (new) resources to use and how to combine resources, the motivation of human resources plays a key role in how these resources are combined. Therefore, the motivation of organizational members is the starting point for the realization of higher level strategic goals (e.g. organizational performance). Moreover, they point out that organizational teams are forms of human cooperation, where joint production can take place. Thus cues for joint effort of offshore and onshore employees provide an essential normative goal frame for employees. This would help to avoid some of the conflicts of interests between onshore and offshore employees observed in previous research (e.g. [49, 55]).

Accordingly, what motivates individuals towards team-based cooperation is focal for the workings of joint production in a firm [56]. Following GFT, they contend that a "we-frame" instead of an "I-frame" is needed to gear collaborative activities in teams [56, p. 374]. Similarly, we argue that a determinant for the successful implementation of a services offshoring strategy is the establishment of a "we-frame" among onshore and offshore employees. Moreover, when employees are in a normative goal frame, coordination costs (i.e. the need for planning and operationallevel governance) are reduced, because they hold a shared understanding of actions and interactions in terms of collective goals [19, p. 91]. Along these lines, we suggest that joint production motivation will enable services offshoring firms to minimize coordination costs in offshoring arrangements and gain offshoring capabilities and resources.

\section{Proposition 1b (P1b)}

Joint production motivation in services offshoring is a prerequisite for strategy implementation and thereby for achieving the intended offshoring outcomes.

\subsection{The Role of Interpersonal Relationships and Relational Signals in the Implementation of a Services Offshoring Strategy}

GFT further suggests that interpersonal relationships play a role in goal framing. In detail, the goals that other people hold in one's social environment influence one's own goals [57, p. 64]. This mechanism is what Lindenberg refers to as "goal contagion" [51, p. 672]. In the context of services offshoring strategy implementation, when individuals engage in goal framing which will motivate them to carry out a particular strategy, the mental models of the interpersonal relationships will shape part of their goal framing. These relationships can be formal (e.g. with a manager) and / or informal (e.g. with a colleague). Moreover, the behaviors of others within hierarchical and cooperative relationships may stabilize (or not) the employee's goal frames (i.e. via relational signals). 
Therefore, relational signals (i.e. the way employees interpret the actions of others) between onshore and offshore employees, as well as relational signals between managers and employees in each site, may play a role in stabilizing the normative goal frames or hindering gain and hedonic ones and thereby joint production motivations can support the successful implementation of a services offshoring strategy. For example, Zimmermann et al. [46] suggest that offshoring attitudes of onshore employees influence their relational behaviors towards offshore employees (e.g. treating them as colleagues instead of external suppliers) and that these behaviors feed back into their attitudes, by creating vicious or virtuous circles of offshoring collaboration. Moreover, Zimmermann et al. [46] advise that managers should also show positive offshoring attitudes and behaviors themselves. Hence, what Zimmermann et al. [46] describe is very similar to the outcomes of the contagion effect of goal frames based on relational signals.

\section{Proposition 2 (P2)}

Interpersonal relationships and relational signals can stabilize or hinder normative goal frames and thereby joint production motivation, which affects employee motivation to implement a services offshoring strategy.

Although scholars have already addressed the relevance of relational signals during services offshoring implementation, they have not gone so far as to provide a mechanism that explicitly links them with the realized strategy outcomes. Thus we strongly believe that future research will benefit from examining this link. Moreover our proposition has practical implications for governance in services offshoring. Relational positive performance feedback (formal or informal) is considered an effective mechanism for stabilizing normative goal frames [58, p. 53]. Therefore, we suggest that managers dealing with the services offshoring arrangements should plan and execute the strategy in a way that translates into structures and activities enabling both onshore and offshore employees to achieve an understanding of shared tasks, labor and rewards. Furthermore, managers should provide feedback clearly geared towards collective goals and provide rewards that support them.

\subsection{Services Offshoring Strategies That Trigger Knowledge Sharing Behaviors}

GFT can also provide the lens to explain motivational processes for knowledge sharing, which is one of the major issues that scholars have already addressed in services offshoring research [16, 46-48, 55]. In particular, Foss and Milagres [50] suggest that a joint production motivation enables knowledge transfer and knowledge integration. Based on this assumption, we suggest that if a services offshoring strategy triggers normative goal frames, knowledge sharing behaviors of onshore and offshore employees will increase.

\section{Proposition 3 (P3)}


A services offshoring strategy that triggers normative goal frames in employees will increase knowledge sharing behaviors between onshore and offshore employees.

As we reviewed, extant offshoring research suggests that knowledge seeking is one of the major firm level criteria for services offshoring decisions. In line with the $\mathrm{KBV}$, knowledge resources are considered as important services offshoring strategy outcomes. However, within the context of services offshoring it is not clear how employees are motivated to share their knowledge and therefore contribute to macrolevel strategy outcomes. We contend that the above research proposition provides the means to explore the link between "knowledge seeking" services offshoring firms and knowledge resources as a firm level construct.

Apart from implications for research, we hope that this proposition also offers guidance for governance tools in services offshoring. In detail we hold that an action of implementing the strategy involves knowledge sharing. For example, if tasks and rewards are linked to joint outcomes [50, 59], it is likely that (within services offshoring arrangements) onshore employees are not afraid of losing their jobs [cf. 47] and therefore, are motivated to share knowledge [46]. Similarly, shared goals, trust and good communication as determinants of knowledge sharing [48] are in line with a joint production motivation. Furthermore, building upon the model of knowledge transfer in IT offshoring by Zimmermann and Ravishankar [49], we believe that knowledge senders' outcome expectations (e.g. contribution to a common goal) and efficacy beliefs (e.g. the belief that an individual can contribute to shared knowledge) can be tied to a normative goal frame. When these are combined with social capital (e.g. through intensive communication, shared team identity, trust and a shared contextual understanding), they can lead to effective knowledge sharing in services offshoring.

\section{Conclusions}

In recent years, scholars have suggested that offshoring systematically entails more knowledge intensive, high value, innovative, non-routine activities in the services sector (see e.g. [10, 11, 29]). In this context, they explored various firm level criteria for services offshoring decisions that describe the initial firm motivations such as cost efficiency and knowledge seeking [35]. However, extant research on firm-level criteria for services offshoring decisions does not provide a clear view on how these decisions result in specific services offshoring outcomes. In parallel, researchers have addressed the role of micro-processes and especially the role of employee motivational processes in services offshoring implementation. Nevertheless, the corresponding micro-research does not provide comprehensive explanations of the links between employee motivational processes, services offshoring strategy implementation and its macro-level outcomes.

Understanding services offshoring implementation in terms of its realized outcomes is fascinating but challenging. We therefore proposed a conceptual model that focuses on employee motivation in implementing services offshoring strategies. In other words, the proposed model accounts for the employee-level microfoundations 
of services offshoring strategy. Its importance is its explanatory power. In detail, it links service offshoring strategy attributes and the realized outcomes of the strategy, with employee motivational processes that lead to actions and interactions and facilitate (or not) the implementation of the services offshoring strategy. Thus we contend that our proposed model can help to bridge the two complimentary streams of research that explore (a) firm level services offshoring attributes and outcomes and (b) micro-level processes linked with services offshoring. Furthermore, we developed three propositions to advocate that in order to investigate services offshoring outcomes, scholars and practitioners should use GFT to consider possible links of these outcomes with employee level processes in services offshoring. Hence, the model also offers a guiding tool for governance in services offshoring arrangements and introduces a new starting point for future empirical research.

\section{References}

1. Booth, T.: Here, there and everywhere-special report: Outsourcing and offshoring. Econ, (2013)

2. Jensen, P.D.Ø., Larsen, M.M., Pedersen, T., (Eds): Developing offshoring capabilities for the contemporary offshoring organization [Special issue]. J. Int. Manag. 19, (2013)

3. UNCTAD: World Investment Report 2004: The Shift Towards Services. United Nations, New York and Geneva (2004)

4. Doh, J.P.: Offshore Outsourcing: Implications for International Business and Strategic Management Theory and Practice. J. Manag. Stud. 42, 695-704 (2005)

5. Bunyaratavej, K., Doh, J., Hahn, E.D., Lewin, A.Y., Massini, S.: Conceptual Issues in Services Offshoring Research: A Multidisciplinary Review. Gr. Organ. Manag. 36, 70-102 (2011)

6. Pisani, N., Ricart, J.E.: Offshoring of Services: A Review of the Literature and Organizing Framework. Manag. Int. Rev. 56, 385-424 (2016)

7. Manning, S., Massini, S., Lewin, A.Y.: A Dynamic Perspective on Next-Generation Offshoring: The Global Sourcing of Science and Engineering Talent. Acad. Manag. Perspect. 22, 35-54 (2008)

8. Lewin, A.Y., Peeters, C.: Offshoring Work: Business Hype or the Onset of Fundamental Transformation? Long Range Plann. 39, 221-239 (2006)

9. Lahiri, S., Kedia, B.L., Mukherjee, D.: The impact of management capability on the resource-performance linkage: Examining Indian outsourcing providers. J. World Bus. 47, 145-155 (2012)

10. Jensen, P.D.Ø., Pedersen, T.: Offshoring and international competitiveness: Antecedents of offshoring advanced tasks. J. Acad. Mark. Sci. 40, 313-328 (2012)

11. Lewin, A.Y., Massini, S., Peeters, C.: Why are companies offshoring innovation? The emerging global race for talent. J. Int. Bus. Stud. 40, 901-925 (2009)

12. Larsen, M.M., Manning, S., Pedersen, T.: Uncovering the hidden costs of offshoring: The interplay of complexity, organizational design, and experience. Strateg. Manag. J. 34, 533-552 (2013)

13. Jensen, P.D.Ø.: A learning perspective on the offshoring of advanced services. J. Int. Manag. 15, 181-193 (2009)

14. Jensen, P.D.Ø.: A passage to India: A dual case study of activities, processes and resources in offshore outsourcing of advanced services. J. World Bus. 47, 311-326 (2012)

15. Mattarelli, E., Tagliaventi, M.R.: How Offshore Professionals’ Job Dissatisfaction Can 
Promote Further Offshoring: Organizational Outcomes of Job Crafting. J. Manag. Stud. 52, 585-620 (2012)

16. Zimmermann, A., Ravishankar, M.N.: A systems perspective on offshoring strategy and motivational drivers amongst onshore and offshore employees. J. World Bus. 51, 548-567 (2016)

17. Felin, T., Foss, N.J., Ployhart, R.E.: The Microfoundations Movement in Strategy and Organization Theory. Acad. Manag. Ann. 9, 575-632 (2015)

18. Manning, S.: Mitigate, tolerate or relocate? Offshoring challenges, strategic imperatives and resource constraints. J. World Bus. 49, 522-535 (2014)

19. Foss, N.J., Lindenberg, S.M.: Microfoundations for strategy: a goal-framing perspective on the drivers of value creation. Acad. Manag. Perspect. 27, 85-102 (2013)

20. Lindenberg, S., Foss, N.J.: Managing joint production motivation: The role of goal framing and governance mechanisms. Acad. Manag. Rev. 36, 500-525 (2011)

21. Bunyaratavej, K., Hahn, E.D., Doh, J.P.: International offshoring of services: A parity study. J. Int. Manag. 13, 7-21 (2007)

22. Hätönen, J., Eriksson, T.: 30+ years of research and practice of outsourcing Exploring the past and anticipating the future. J. Int. Manag. 15, 142-155 (2009)

23. Sako, M.: Outsourcing and Offshoring of Professional Services. In: Empson, L., Muzio, D., Broschak, J., and Hinings, B. (eds.) The Oxford Handbook of Professional Service Firms. pp. 327-347. Oxford University Press, Oxford (2015)

24. Porter, M.E.: The Competitive Advantage: Creating and Sustaining Superior Performance. Free Press, New York (1985)

25. Maskell, P., Pedersen, T., Petersen, B., Dick-Nielsen, J.: Learning Paths to Offshore Outsourcing: From Cost Reduction to Knowledge Seeking. Ind. Innov. 14, 239-257 (2007).

26. Gerbl, M., McIvor, R., Loane, S., Humphreys, P.: A multi-theory approach to understanding the business process outsourcing decision. J. World Bus. 50, 505-518 (2015).

27. Martinez-Noya, A., Garcia-Canal, E., Guillen, M.F.: International R\&D service outsourcing by technology-intensive firms: Whether and where? J. Int. Manag. 18, 1837 (2012)

28. Teece, D.J., Pisano, G., Shuen, A.: Dynamic capabilities and strategic management. Strateg. Manag. J. 18(7), 509-533 (1997)

29. Contractor, F.J., Kumar, V., Kundu, S.K., Pedersen, T.: Reconceptualizing the firm in a world of outsourcing and offshoring: The organizational and geographical relocation of high-value company functions. J. Manag. Stud. 47, 1417-1433 (2010)

30. Mudambi, R., Venzin, M.: The strategic nexus of offshoring and outsourcing decisions. J. Manag. Stud. 47, 1510-1533 (2010)

31. Dunning, J.H.: Location and the multinational enterprise: a neglected factor?. J. Int. Bus. Stud. 29(1), 45-66 (1998)

32. Dunning, J.H.: The eclectic (OLI) paradigm of international production: past, present and future. Int. J. Econ. Bus. 8, 173-190 (2001)

33. Lewin, A.Y., Peeters, C.: Offshoring Work: Business Hype or the Onset of Fundamental Transformation? Long Range Plann. 39, 221-239 (2006)

34. Pisani, N., Ricart, J.E.: Offshoring and the Global Sourcing of Talent : Understanding the New Frontier of Internationalization. In: Proceedings of 2nd Annual Offshoring Research Network Conference and Workshop. pp. 1-45. , Philadelphia (2008)

35. Roza, M., Van den Bosch, F.A.J., Volberda, H.W.: Offshoring strategy: Motives, functions, locations, and governance modes of small, medium-sized and large firms. Int. Bus. Rev. 20, 314-323 (2011)

36. Oshri, I., Kotlarsky, J., Willcocks, L.P.: The Handbook of Global Outsourcing and 
Offshoring. Palgrave Macmillan, London (2015)

37. Lioliou, E., Zimmermann, A., Willcocks, L., Gao, L.: Formal and relational governance in IT outsourcing: substitution, complementarity and the role of the psychological contract. Inf. Syst. J. 24, 503-535 (2014)

38. Srikanth, K., Puranam, P.: Integrating distributed work: comparing task design, communication, and tacit coordination mechanisms. Strateg. Manag. J. 32, 849-875 (2011)

39. Schmeisser, B.: Journal of International Management A Systematic Review of Literature on Offshoring of Value Chain Activities. J. Int. Manag. 19, 390-406 (2013)

40. Di Gregorio, D., Musteen, M., Thomas, D.E.: Offshore outsourcing as a source of international competitiveness for SMEs. J. Int. Bus. Stud. 40, 969-988 (2008)

41. Zimmermann, A., Ravishankar, M.N.: Collaborative IT offshoring relationships and professional role identities: Reflections from a field study. J. Vocat. Behav. 78, 351360 (2011)

42. Sidhu, J.S., Volberda, H.W.: Coordination of globally distributed teams: A coevolution perspective on offshoring. Int. Bus. Rev. 20, 278-290 (2011).

43. Levina, N., Vaast, E.: Innovating or doing as told? Status differences and overlapping boundaries in offshore collaboration. MIS Q. 32, 307-332 (2008)

44. van Marrewijk, A.: Situational construction of Dutch-Indian cultural differences in global IT projects. Scand. J. Manag. 26, 368-380 (2010)

45. Jensen, R.E., Nardi, B.: The Rhetoric of Culture as an Act of Closure in a CrossNational Software Development Department. Paper presented at 22nd European Conference on Information Systems. AIS, Tel-Aviv, 9-11 June 2014

46. Zimmermann, A., Raab, K., Zanotelli, L.: Vicious and virtuous circles of offshoring attitudes and relational behaviours. A configurational study of German IT developers. Inf. Syst. J. 23, 65-88 (2013).

47. Mahadevan, J.: Power / Knowledge in postcolonial settings: The case of IT Bangalore. Intercult. J. 10, 61-81 (2011)

48. Rottman, J.W.: Successful knowledge transfer within offshore supplier networks: a case study exploring social capital in strategic alliances. J. Inf. Technol. 23, 31-43 (2008)

49. Zimmermann, A., Ravishankar, M.N.: Knowledge transfer in IT offshoring relationships: the roles of social capital, efficacy and outcome expectations. Inf. Syst. J. 24, 167-202 (2014).

50. Foss, N.J., Milagres, R.: Pro-social Motivation beyond Firm Boundaries: The Case of the Genolyptus Network. BAR - Brazilian Adm. Rev. 11, 364-384 (2014)

51. Lindenberg, S.: Social Rationality, Semi-Modularity and Goal-Framing: What Is It All About? Anal. Krit. 30, 669-687 (2008)

52. Cohen, L., El-Sawad, A.: Lived experiences of offshoring: An examination of UK and Indian financial service employees' accounts of themselves and one another. Hum. Relations. 60, 1235-1262 (2007).

53. Dibbern, J., Winkler, J., Heinzl, A.: Explaining variations in client extra costs between software projects offshored to india. MIS Q. 32(2), 333-366 (2008)

54. Lacity, M.C., Iyer, V. V., Rudramuniyaiah, P.S.: Turnover intentions of Indian IS professionals. Inf. Syst. Front. 10, 225-241 (2008).

55. Metiu, A.: Owning the Code: Status Closure in Distributed Groups. Organ. Sci. 17, 418-435 (2006).

56. Foss, N.J., Lindenberg, S.: Teams, Team Motivation, and the Theory of the Firm. Manag. Decis. Econ. 33, 369-383 (2012).

57. Lindenberg, S.: The cognitive side of governance. In: Buskens, V., Raub, W., and Snijders, C. (eds.) The Governance of Relations in Markets and Organizations, Research in the Sociology of Organizations. pp. 47-76. Emerald Group Publishing 
Limited (2003)

58. Lindenberg, S.: Governance seen from a framing point of view: The employment relationship and relational signalling. In: Nooteboom, B. and Six, F. (eds.) The trust process in organizations: empirical studies of the determinants and the process of trust development. pp. 37-57. Edward Elgar, Cheltenham (2003)

59. Lindenberg, S.: Cognition and governance: why incentives have to take a back seat. In: Grandori, A. (ed.) Handbook of Economic Organisation - Integrating Economic and Organization Theory. pp. 41-61. Edward Elgar, Cheltenham (2013) 